\title{
PENGARUH KOMUNIKASI PEMASARAN TERPADU TERHADAP KEPUTUSAN PEMBELIAN PENGUNJUNG SERTA DAMPAKNYA PADA KEPUTUSAN PERPANJANGAN SEWA PENYEWA KIOS DI PALEMBANG SQUARE MALL (PS MALL)
}

\author{
Agustina Hanafi dan Zakaria Wahab \\ Fakultas Ekonomi Universitas Sriwijaya \\ Email: tinahanafi@ymail.comdanzkwahab@yahoo.com
}

\begin{abstract}
The aim of this research is to determine the influence of integrated marketing communication to visitor's purchasing decisions and their impact on tenant's decisions for renewing contract in Palembang Square Mall. The research was conducted by distributing questionnaires to 135 visitors of PS Mall and 101 tenant leases at PS Mall. This research is using Structural Equation Modeling (SEM) with AMOS program to analyze the data. The results indicate that integrated marketing communication of PS Mall significantly influence the purchasing decision of visitors but has no significant effect on tenant's decision for renewing contract. The results also indicate that visitor's purchase decision also has no significant influence to tenant's decision for renewing contract in Palembang Square Mall.
\end{abstract}

Keywords: Integrated Marketing Communication, Purchase Decision, Tenant's Contract Renew, Mall

\begin{abstract}
Abstrak: Tujuan dari penelitian ini adalah untuk mengetahui pengaruh komunikasi pemasaran terpadu untuk keputusan pembelian pengunjung dan dampaknya terhadap keputusan penyewa untuk memperbaharui kontrak di Palembang Square Mall. Penelitian ini dilakukan dengan menyebarkan kuesioner kepada 135 pengunjung PS Mall dan 101 sewa tenant di PS Mall. Penelitian ini menggunakan Structural Equation Modeling (SEM) dengan program AMOS untuk menganalisis data. Hasil penelitian menunjukkan bahwa komunikasi pemasaran terpadu dari PS Mall berpengaruh signifikan terhadap keputusan pembelian pengunjung tetapi tidak berpengaruh signifikan terhadap keputusan penyewa untuk memperbaharui kontrak. Hasil penelitian juga menunjukkan bahwa keputusan pembelian pengunjung juga tidak memiliki pengaruh yang signifikan terhadap keputusan penyewa untuk memperbaharui kontrak di Palembang Square Mall.
\end{abstract}

Kata kunci: Marketing Communication Terpadu, Keputusan Pembelian, Tenant Kontrak Renew, Mall

\section{PENDAHULUAN}

Hadirnya pusat perbelanjaan saat ini membuat masyarakat mulai beralih tempat belanja dari pasar tradisional ke pusat perbelanjaan yang lebih modern. Definisi pusat perbelanjaan sendiri menurut Peraturan Menteri Perdagangan Republik Indonesia No. 70/M-DAG/PER/12/2013 adalah "Suatu area tertentu yang terdiri dari satu atau beberapa bangunan yang didirikan secara vertikal maupun horisontal, yang dijual atau disewakan kepada pelaku usaha atau dikelola sendiri untuk melakukan kegiatan perdagangan 
barang”. Di pusat perbelanjaan yang lebih modern, pelanggan bisa mendapatkan nilai yang lain dibanding berbelanja di pasar tradisional. Pelanggan dapat melihat, memilih dan mengambil sendiri barang-barang yang diperlukan ketika berbelanja dengan tempat yang lebih bersih dan nyaman. Walaupun di pusat perbelanjaan modern harga yang dijual relatif tetap dan tidak bisa ditawar, namun gaya hidup di kota besar yang cenderung mementingkan efisiensi membuat pusat perbelanjaan menjadi pilihan masyarakat untuk berbelanja.

Pusat perbelanjaan di kota Palembang seperti PS Mall, Palembang Trade Center, Palembang Indah Mall, Palembang Icon, Lippo Plaza Jakabaring, OPI Mall Jakabaring menciptakan alternatif pilihan tempat belanja bagi masyarakat kota Palembang. Tidak hanya Ramayana dan operator mall seperti Lippomalls saja, tetapi pengusaha lokal pun tertarik untuk mengambil peluang bisnis pusat perbelanjaan di kota Palembang. Tahun 2011, Lippomalls masuk ke Palembang dengan mengakuisisi PS Mall, kemudian membangun mall baru yaitu Lippo Plaza Jakabaring dan Palembang Icon. Sedangkan International Plaza, Palembang Trade Center, Palembang Indah Mall dan OPI Mall Jakabaring masing-masing dibangun dan dikelola oleh pengusaha lokal.

Persaingan ini membuat pengelola pusat perbelanjaan harus merancang strategi yang tepat untuk mengantisipasi adanya perubahan lingkungan dan persaingan agar dapat mencapai dan mempertahankan keberhasilan pengelola pusat perbelanjaan dalam jangka panjang. Pengelola pusat perbelanjaan harus jeli dalam mengidentifikasi kesempatankesempatan dan ancaman-ancaman yang berada di sekitarnya dan jeli dalam memahami kebutuhan dan keinginan pelanggan agar dapat memenuhi harapan mereka sehingga pelanggan tidak akan berpikir untuk mencari alternatif lain dan mengungguli perusahaan pesaing.

Pengelola pusat perbelanjaan sebagai penyedia jasa sewa kios, harus benar-benar memperhatikan kebutuhan dan masalah yang dihadapi oleh pelanggan utama (primary customer) mereka yaitu para penyewa kios karena pendapatan utama pusat perbelanjaan berasal dari sewa kios, seperti Nasir et.al (2013:356) yang menyatakan bahwa: "Shopping centres gain benefits through the payment of rentals, directly from the primary customers, which comprise of tenants. Therefore it is critical for landlord to maintain and continue to attract tenants to operate in the shopping centre". Menurut Sinchaloenman \& Ngamyan (2013:1) “Changing tenant increases operating expense and decrease rental income”, ini berarti loyalitas tenant sangat penting bagi pusat perbelanjaan. Pergantian tenant yang terus-menerus malah akan meningkatkan biaya operasional karena harus mengeluarkan biaya pemeliharaan dan menurunkan pendapatan sewa (rental income) selama tenant kosong. Hubungan antara pusat perbelanjaan, pengunjung dan tenant sangat erat, seperti pernyataan Sinchaloenman \& Ngamyan (2013:1) bahwa: "Shopping mall gets rent from tenant that reflects to tenant's profit and ability to pay. To encourage tenant's profit, shopping mall has to have a strong marketing strategy to communicate with customers who are spender to tenant. By this, tenant gets maximum profit and shopping mall can ask for maximum market rental rate in a renew contract". Penjualan tenant yang berasal dari transaksi pembelian yang dilakukan oleh pengunjung mempengaruhi besar laba yang diperoleh oleh tenant. Dengan demikian amatlah penting bagi pengelola pusat perbelanjaan untuk memastikan kemampuan bayar tenant dengan membantu meningkatkan penjualan tenant melalui strategi komunikasi pemasaran (marketing communication Transaksi pengunjung yang secara tidak langsung mempengaruhi kelangsungan hidup pusat perbelanjaan, menjadikan pengunjung sebagai pelanggan kedua 
(secondary customer) bagi sebuah pusat perbelanjaan.

Menurut Rini (2009:15) saat era services economy dan service excellence, barang dan layanan yang bagus sudah cukup untuk memuaskan pelanggan. Karena itulah kepuasan pelanggan kemudian menjadi ukuran kesuksesan sebuah merek. Namun kini, kita telah memasuki era experiential economy. Untuk itulah, produk harus mampu membangkitkan sensasi dan pengalaman yang akan menjadi basis loyalitas pelanggan. Karena pergeseran ini, maka konsep kepuasan pelanggan kini menjadi kurang relevan. Adapun agen-agen atau experience producer (ExPros) yang dapat menghantarkan pengalaman (experience) ini adalah komunikasi yang meliputi iklan, komunikasi perusahaan baik internal maupun eksternal dan public relation; indentitas dan tanda baik visual maupun verbal, meliputi nama, logo, warna dan lain-lain; tampilan produk baik design, kemasan maupun penampakan; co-branding yang meliputi event-event pemasaran, sponsorship, aliansi dan rekanan kerja, lisensi, penempatan produk dalam film dan sebagainya.

Lingkungan spatial yang termasuk desain kantor, baik interior maupun eksterior, outlet penjualan, ekshibisi penjualan dan lain-lain, website, orang yang meliputi penjual, representasi perusahaan, customer service, operator call centre dan lainnya. Dari agenagen tersebut terlihat bahwa bauran komunikasi pemasaran (marketing communication mix) termasuk agen yang dapat mengantarkan pengalaman (experience), dimana menurut Kotler \& Keller (2012:478) bauran komunikasi pemasaran itu sendiri terdiri atas 8 cara komunikasi utama yaitu: iklan, promosi penjualan, hubungan masyarakat dan publisitas/pemberitaan, acara khusus dan pengalaman, pemasaran langsung, pemasaran interaktif (interactive marketing), word of mouth marketing dan personal selling.

PS Mall adalah salah satu pusat perbelanjaan yang turut meramaikan bisnis pusat perbelanjaan di Palembang semenjak Agustus 2004. Salah satu strategi yang dilakukan oleh PS Mall untuk menarik pengunjung datang dan berbelanja adalah dengan menciptakan pengalaman berbelanja (shopping experience) yang menarik bagi pengunjung dan mengagendakannya kedalam kalender pemasaran (marketing calendar) setiap tahunnya. Dengan campaignnya yang berbunyi “ENJOY EXPLORE” di tahun 2015, Palembang Square Mall berusaha menciptakan pengalaman berbelanja (shopping experience) bagi pengunjung dengan menciptakan acara khusus bertema (thematic event) dilengkapi dengan promosi penjualan (sales promotion) yang kemudian diiklankan dan dipublikasikan melalui media massa seperti surat kabar. Selain itu digunakan juga website dan media sosial seperti facebook, twitter, instagram dan path sebagai media komunikasi dengan pemasaran langsung dan bersifat interaktif. Seluruh karyawan, khususnya resepsionis dan customer service juga digerakkan sebagai media komunikasi pemasaran. Pengalaman berbelanja (shopping experience) menarik yang telah diciptakan dan dirangkum dalam kalender pemasaran kemudian dikomunikasikan kepada pengunjung dan tenant melalui strategi komunikasi pemasaran (marketing communication) yang telah terintegrasi dengan tujuan untuk meningkatkan transaksi pembelian pengunjung di tenanttenant.

Walaupun strategi komunikasi pemasaran terpadu untuk meningkatkan tingkat penjualan tenant ini telah diterapkan oleh PS Mall, tetapi tenyata di tahun 2015 terlihat gejala penurunan pengunjung sebesar 4, 03\% dan penurunan tingkat hunian sebesar 4,85\% dari tahun sebelumnya yang disebabkan kontrak sewa yang tidak dilanjutkan kembali oleh tenant. Dari informasi yang didapatkan dari pengelola PS Mall, rata-rata penyewa kios tidak memperpanjang kontrak sewa kios karena tidak mampu membayar sewa. 
Ketidakmampuan ini karena biaya operasional mereka lebih besar dari pada pendapatan yang diterima. Hal ini membuat peneliti ingin mengetahui efektifitas dari upaya pengelola PS Mall untuk membantu penjualan tenant melalui strategi komunikasi pemasaran terpadu dalam mempengaruhi keputusan pembelian pengunjung.

Penelitian mengenai Integrated Marketing Communication (IMC) juga pernah dilakukan di salah satu mall di Indonesia oleh Widya (2007) yang menyatakan bahwa perilaku konsumen seperti belanja, makan, nonton bioskop, melihat pertunjukan, bertemu, dan berbincang-bincang di mall dipengaruhi secara signifikan oleh Integrated Marketing Communication (IMC) yang dilakukan manajemen Mall Kelapa Gading. Penelitian lain mengenai komunikasi pemasaran terpadu dilakukan oleh Haqie (2015) dan Devvy (2013) yang membahas komunikasi pemasaran terpadu yang dilakukan oleh mall dalam meningkatkan jumlah pengunjung.

Penelitian-penelitian tersebut hanya mempelajari hubungan antara manajemen mall dan pengunjung mall (secondary customer) tetapi tidak meneliti pengaruhnya terhadap tenant sebagai tujuan utama diterapkannya strategi komunikasi pemasaran tersebut. Oleh sebab itu, peneliti mencoba untuk meneliti hubungan antara ketiga pihak tersebut yaitu pengelola mall, pengunjung dan tenant dengan meneliti seberapa besar pengaruh strategi komunikasi pemasaran terpadu tersebut mendorong keputusan pembelian pengunjung dan seberapa besar dampak keputusan pembelian pengunjung tersebut mempengaruhi penyewa kios (tenant lease) untuk memperpanjang kontrak sewanya.

\section{KAJIAN TEORI}

Pengertian Komunikasi Pemasaran Terpadu (IMC). Komunikasi pemasaran terpadu (IMC) menurut Shimp (2010:10) adalah proses komunikasi mulai dari perencanaan, kreasi, integrasi dan implementasi dari beberapa bentuk komunikasi pemasaran yang berbeda yang disampaikan serentak ke pelanggan yang dituju. Hermawan (2012:52) adalah menyatukan perencanaan, tindakan dan koordinasi pada semua wilayah komunikasi pemasaran dan juga memahami pelanggan menyangkut apa sesungguhnya tanggapan pelanggan.

Model komunikasi pemasaran terpadu (IMC). Model komunikasi pemasaran terintegrasi mencoba untuk mengintegrasikan semua unsur bauran promosi yang ada dengan asumsi bahwa tidak ada satu unsur pun yang terpisah dalam mencapai tujuan pemasaran yang efektif.

Peter \& Olson (2010:194) mengatakan dalam bisnis retail ada beberapa tahapan perilaku yang umumnya berlaku pada pelanggan yang berbelanja. Tahapan ini dimulai dari kontak informasi (information contact), akses dana (funds access), kontak dengan toko (store contact), kontak dengan produk (product contact), melakukan transaksi, mengkonsumsi dan disposisi, kemudian diakhiri dengan komunikasi dengan pihak lain.

Pengambilan Keputusan Konsumen. Peter \& Olson (2010:160) mengatakan kunci dari proses pengambilan keputusan konsumen adalah proses integrasi dimana pengetahuan dikombinasikan untuk mengevaluasi dua atau lebih perilaku alternatif dan kemudian memilih satu diantaranya. Hasil dari proses integrasi ini adalah pilihan, yang mewakili secara kognitif sebagai niat perilaku. 
Keputusan Perpanjangan Sewa Kios. Pendapatan utama dari mall berasal dari penyewa kios (tenant lease), maka dari itu penyewa kios (tenant lease) adalah pelanggan utama dari mall. Keputusan tenant untuk menyewa dan memperpanjang kontrak sewa adalah salah satu hal yang mendukung kelangsungan dan kesuksesan mall.

Menurut Lovelock \& Wirtz (2011:345), ada 3 tahap dalam membentuk loyalitas pelanggan yaitu membangun dasar yang kuat kemudian menciptakan ikatan agar pelanggan mereka lebih dekat dan mengurangi kehilangan pelanggan. Menurut Lovelock \& Wirtz (2011:346), membangun dasar yang kuat untuk loyalitas dapat dilakukan dengan beberapa cara yaitu mencari pelanggan yang tepat, mencari nilai (value) bukan hanya volume, mengelola data pelanggan melalui ikatan jasa yang efektif dan kepuasan pelanggan dan kualitas layanan adalah syarat awal terbentuknya loyalitas

Sedangkan untuk menciptakan ikatan yang lebih dekat dengan pelanggan menurut Lovelock \& Wirtz (2011:345) dapat dilakukan cara mendalamkan hubungan (deeping the relationship), mendorong keloyalitasan dengan memberikan penghargaan finansial (misalnya dengan pemberian diskon pada saat pembelian) maupun non-finansial yaitu dengan pemberian manfaat atau keuntungan dan yang terakhir, perusahaan juga harus berusaha mengurangi terjadinya kehilangan pelanggan. Lovelock \& Wirtz (2011:358) mengatakan untuk menghilangkan atau mengurangi faktor pendorong terjadinya kehilangan pelanggan dapat dilakukan cara menganalisa kehilangan pelanggan dan memonitor angka penurunan, mencegah pendorong utama terjadinya kehilangan pelanggan dan menerapkan penangganan keluhan yang efektif dan prosedur pemulihan jasa serta meningkatkan biaya pengalihan.

Kerangka Pikir. Pengelola mall harus melakukan strategi pemasaran yang tepat untuk meningkatkan pengunjung mall serta menarik dan mempertahankan tenant. Mall sebagai media yang memfasilitasi terjadinya transaksi antara tenant dan pengunjung sebagai pembeli haruslah mempunyai strategi komunikasi pemasaran yang kuat agar dapat mempengaruhi pengunjung untuk datang dan melakukan pembelian. Strategi komunikasi pemasaran ini dapat dilakukan secara terintegrasi atau sering disebut sebagai komunikasi pemasaran terpadu (Integrated Marketing Communication).

Pada penelitian Tendai \& Crispen (2009) diketahui promosi penjualan pada retail store berupa kupon dan voucher ternyata mempunyai pengaruh terhadap pembelian. Citra baik perusahaan yang dihasilkan melalui publisitas pada penelitian Alam (2015), diketahui mempunyai berpengaruh positif terhadap keputusan pembelian. Penelitian mengenai acara khusus dan pengalaman juga pernah dilakukan oleh Avello et.al (2013) dimana dinyatakan bahwa menciptakan pengalaman belanja yang menyenangkan juga mempunyai pengaruh terhadap pembelian. Dengan menghabiskan waktu berbelanja lebih lama dari yang direncanakan maka kemungkinan pelanggan untuk melakukan pembelian menjadi lebih tinggi. Sedangkan untuk pemasaran langsung menggunakan website diketahui bahwa intensitas penggunaan dan tampilan website berpengaruh signifikan terhadap keputusan pembelian member online pada penelitian Dwipuspita et.al (2012). Pemasaran interaktif melalui email, chatting, media sosial dapat membuat pelanggan lebih dekat dan mengenal perusahaan. Menurut penelitian Adriyanto \& Haryanto (2010), ternyata pemasaran interaktif ini tidak berpengaruh langsung terhadap keputusan pembelian, tetapi pemasaran interaktif ini berpengaruh langsung terhadap word of mouth. Pada komunikasi pemasaran melalui word of mouth, rekomendasi yang diterima pelanggan melalui jejaring sosial ternyata mempunyai pengaruh positif terhadap keputusan pembelian pada penelitian Adriyanto \& Haryanto (2010). 
Komunikasi pemasaran melalui iklan, promosi penjualan, hubungan masyarakat dan publisitas, pemasaran langsung dan pemasaran interaktif, pemasaran dari mulut ke mulut, dan penjualan personal yang dilakukan secara terpadu atau yang disebut sebagai IMC pada penelitian Larasati (2015), ternyata berpengaruh kuat terhadap keputusan pembelian jasa biro perjalanan wisata. Sedangkan keputusan tenant untuk memperpanjang kontrak sewa, menurut penelitian Sinchaloenman \& Ngamyan (2013) ternyata dipengaruhi oleh performa pengelola mall untuk menarik pengunjung dan strategi pemasarannya.

Pengelolaan semua sumber informasi secara terpadu atau Integrated Marketing Communication (IMC) yang digunakan dan didesain sedemikian rupa oleh mall bertujuan untuk mendorong perilaku pengunjung untuk melakukan pembelian. Pengunjung yang melakukan pembelian dapat meningkatkan penjualan tenant. Strategi komunikasi pemasaran yang dilakukan oleh pengelola mall dapat menjadi nilai tambah (supplementary services) bagi tenant untuk mendukung produk inti mall yaitu penyewaan kios. Dengan bertambahnya manfaat (benefit) yang diterima tenant maka dapat memperkuat terbentuknya loyalitas tenant, hal ini didukung dengan teori dan beberapa penelitian sebelumnya maka didapatlah gambaran kerangka pemikiran seperti pada Gambar 1.

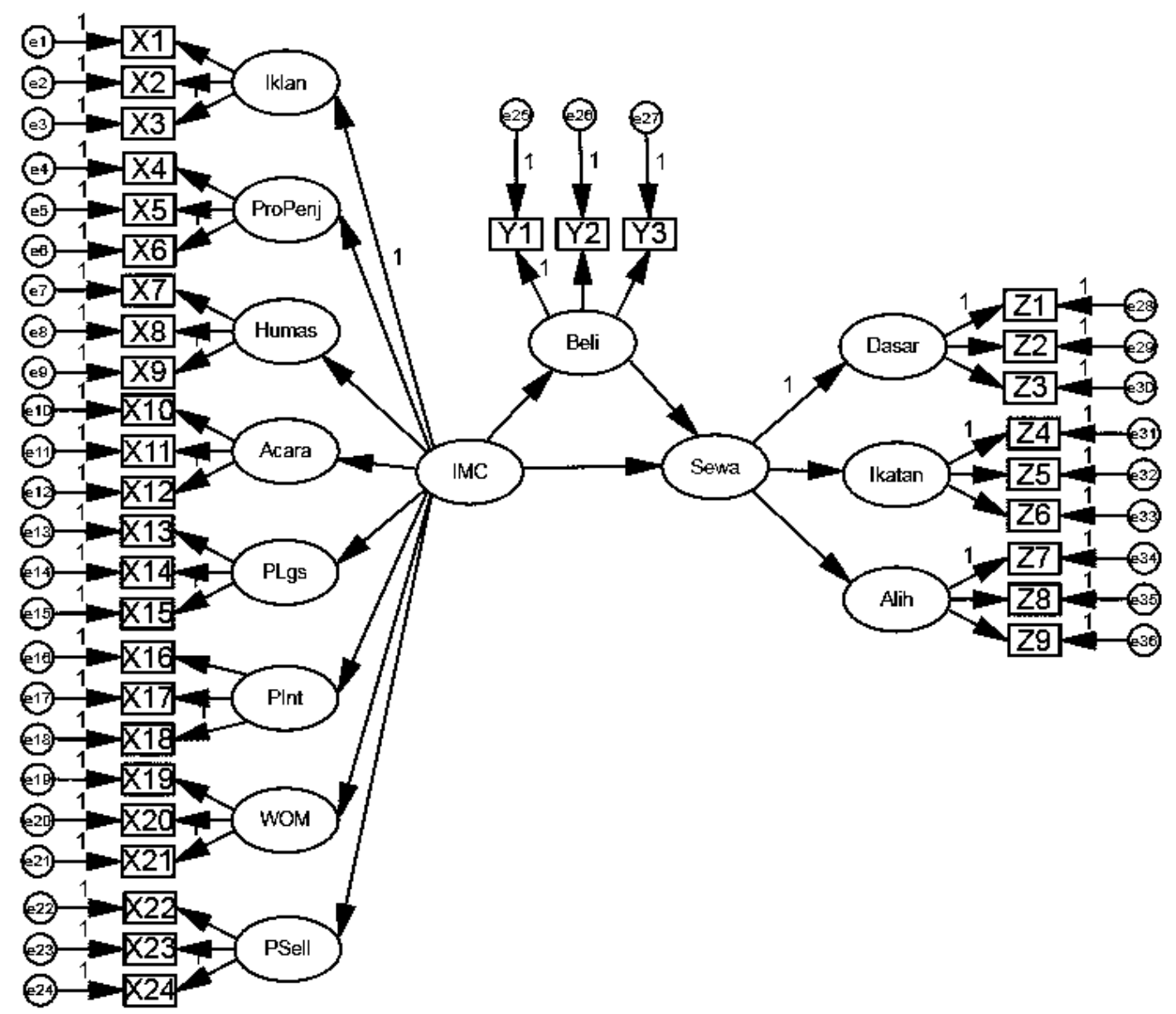

Gambar 1. Kerangka Pemikiran Berdasarkan Telaah Literatur 


\section{METODE}

Populasi dan Sampel. Populasi dari penelitian ada 2 yaitu pengunjung dan penyewa kios (tenant lease) di PS Mall. Jumlah populasi pertama yaitu pengunjung yang berbelanja di PS Mall. Karena jumlahnya sangat besar dan tidak diketahui secara pasti, maka peneliti menggunakan sampel. Menurut Ferdinand (2002:48) jumlah sampel dapat diambil sebesar 5 kali dari jumlah indikator yang digunakan untuk pengunjung yaitu 27 indikator. Dari perhitungan tersebut didapatkan jumlah sampel sebanyak 135 responden. Teknik sampling penelitian yang digunakan adalah Nonprobability Sampling dengan menggunakan sampling accidental. Sedangkan jumlah populasi kedua yaitu penyewa kios (tenant lease) berjumlah 118 tenant yang menyewa $>1$ tahun. Karena jumlah populasi tidak terlalu besar maka semua populasi menjadi responden dari penelitian ini.

\section{Operational variabel penelitian.}

Pengukuran variabel dalam penelitian ini menggunakan skala Likert. Skala penilaian yang dipakai adalah 1 sampai dengan 5, dimana setiap responden diminta pendapatnya mengenai suatu pernyataan. Dari model kerangka pemikiran teoritis, maka definisi operasional variabel dalam penelitian ini diuraikan sebagai berikut:

Tabel 1. Operasional Variabel Penelitian

\begin{tabular}{llcl}
\hline \multicolumn{1}{c}{ Variabel } & Dimensi & Kode & \multicolumn{1}{c}{ Indikator } \\
\hline Komunikasi & Iklan & $\mathrm{X}_{1}$ & Isi pesan jelas \\
Pemasaran & & $\mathrm{X}_{2}$ & Tampilan menarik \\
Terpadu (X) & & $\mathrm{X}_{3}$ & Frekuensi penanyangan \\
& & & \\
Kotler \& Keller & Promosi & $\mathrm{X}_{4}$ & Jenis insentif menarik \\
(2012) & & $\mathrm{X}_{5}$ & Mudah diikuti \\
& Hubungan & $\mathrm{X}_{6}$ & Hadiah beragam \\
& masyarakat & $\mathrm{X}_{7}$ & Kredibilitas berita \\
& dan & $\mathrm{X}_{9}$ & Penggunaan media \\
& publisitas & & \\
& Acara & $\mathrm{X}_{10}$ & Suasana belanja \\
& Khusus dan & $\mathrm{X}_{11}$ & Menarik perhatian \\
& Pengalaman & $\mathrm{X}_{12}$ & Keunikan \\
& & & \\
& Pemasaran & $\mathrm{X}_{13}$ & Tampilan menarik \\
& langsung & $\mathrm{X}_{14}$ & Informasi tepat sasaran \\
& & $\mathrm{X}_{15}$ & Kemudahan informasi \\
& & & \\
& Pemasaran & $\mathrm{X}_{16}$ & Kesadaran pelanggan \\
& Interaktif & $\mathrm{X}_{17}$ & Kemudahan interaksi \\
& & $\mathrm{X}_{18}$ & Kredibilitas informasi
\end{tabular}




\begin{tabular}{|c|c|c|c|}
\hline & $\begin{array}{l}\text { Word of } \\
\text { Mouth }\end{array}$ & $\begin{array}{l}\mathrm{X}_{19} \\
\mathrm{X}_{20} \\
\mathrm{X}_{21}\end{array}$ & $\begin{array}{l}\text { Word of mouth dapat } \\
\text { dipercaya } \\
\text { Word of mouth membantu } \\
\text { menyelesaikan masalah } \\
\text { Pengaruh word of mouth }\end{array}$ \\
\hline & $\begin{array}{l}\text { Personal } \\
\text { selling }\end{array}$ & $\begin{array}{l}X_{22} \\
X_{23} \\
X_{24}\end{array}$ & $\begin{array}{l}\text { Cara penyampaian } \\
\text { Informasi jelas } \\
\text { Membantu menyelesaikan } \\
\text { masalah }\end{array}$ \\
\hline $\begin{array}{l}\text { Keputusan } \\
\text { Pembelian } \\
\text { Pengunjung (Y) } \\
\text { Peter\&Olson } \\
\text { (2010) }\end{array}$ & $\begin{array}{l}\text { Pembelian } \\
\text { (Purchase) }\end{array}$ & $\begin{array}{l}\mathrm{Y}_{1} \\
\mathrm{Y}_{2} \\
\mathrm{Y}_{3}\end{array}$ & $\begin{array}{l}\text { Mendatangi tenant } \\
\text { Produk yang akan dibeli di } \\
\text { tenant } \\
\text { Metode pembayaran }\end{array}$ \\
\hline $\begin{array}{l}\text { Keputusan } \\
\text { Perpanjangan } \\
\text { Sewa Penyewa } \\
\text { Kios (Z) }\end{array}$ & $\begin{array}{l}\text { Dasar } \\
\text { loyalitas }\end{array}$ & $\begin{array}{l}\mathrm{Z}_{1} \\
\mathrm{Z}_{2} \\
\mathrm{Z}_{3}\end{array}$ & $\begin{array}{l}\text { Benefit yang } \\
\text { diterimapenyewa } \\
\text { Kemampuan membayar sewa } \\
\text { Kepuasan penyewa }\end{array}$ \\
\hline & $\begin{array}{l}\text { Ikatan } \\
\text { loyalitas }\end{array}$ & $\begin{array}{l}\mathrm{Z}_{5} \\
\mathrm{Z}_{6} \\
\mathrm{Z}_{7}\end{array}$ & $\begin{array}{l}\text { Perhatian khusus dari } \\
\text { pengelola } \\
\text { Kerjasama dengan pengelola } \\
\text { Mengerti kebutuhan penyewa }\end{array}$ \\
\hline $\begin{array}{l}\text { Lovelock \& } \\
\text { Wirtz (2011) }\end{array}$ & $\begin{array}{l}\text { Peralihan } \\
\text { jasa }\end{array}$ & $\begin{array}{l}\mathrm{Z}_{8} \\
\mathrm{Z}_{9}\end{array}$ & $\begin{array}{l}\text { Mall pesaing } \\
\text { Rekomendasi kepada calon } \\
\text { penyewa baru } \\
\text { Penanganan keluhan }\end{array}$ \\
\hline
\end{tabular}

Metode Analisis Data. Analisis data dalam penelitian ini dilakukan dengan menggunakan Structural Equation Modelling (SEM) dengan variabel laten eksogen adalah Integrated Marketing Communication (X) dan variabel laten endogen adalah Keputusan Pembelian Pengunjung (Y) dan Keputusan Perpanjangan Sewa Kios (Z) dengan 36 indikator.

\section{HASIL DAN PEMBAHASAN}

Structure Equation Modelling dengan Responden Penyewa Kios. Uji Normalitas. Santoso (2015:82) mengatakan pengujian normalitas seharusnya tidak perlu dilakukan, karena secara nature, data ordinal bukan data kuantitatif yang mesti memenuhi asumsi normalitas. Santoso (2015:82) juga mengatakan bahwa dalam banyak riset, walaupun terdapat data yang dikategorikan outlier data tersebut tetap disertakan pada proses pengolahan data. Data pendapat responden betapa pun biasnya, tetap sebuah fakta yang harus diperhitungkan sebagai temuan.

Uji Validitas Konstruk. Berikut ini merupakan hasil validitas pada model struktural, yang dilakukan dengan menggunakan bantuan software AMOS 16. 
Tabel 2. Hasil Uji Validitas Konstruk

\begin{tabular}{|c|c|c|c|c|c|c|c|c|}
\hline & & & $\begin{array}{l}\text { Esti- } \\
\text { mate }\end{array}$ & ACR2 & $<---$ & ACR & .714 & ACR2 \\
\hline KPP & $<---$ & KPT & .679 & ACR1 & $\begin{array}{l}<-- \\
\end{array}$ & ACR & .750 & ACR1 \\
\hline KPSPK & $<---$ & KPP & .239 & LSG3 & $<---$ & LSG & .671 & LSG3 \\
\hline KPSPK & $<---$ & KPT & .263 & LSG2 & $<---$ & LSG & .705 & LSG2 \\
\hline IKL & $<---$ & KPT & .562 & LSG1 & $<---$ & LSG & .811 & LSG1 \\
\hline PRO & $<---$ & KPT & .491 & INT3 & $<---$ & INT & .682 & INT3 \\
\hline HUM & $<---$ & KPT & .605 & INT2 & $<---$ & INT & .745 & INT2 \\
\hline ACR & $<---$ & KPT & .751 & INT1 & $<---$ & INT & .821 & INT1 \\
\hline LSG & $<---$ & KPT & .678 & WOM3 & $<---$ & WOM & .708 & WOM3 \\
\hline INT & $<---$ & KPT & .708 & WOM2 & $<---$ & WOM & .827 & WOM2 \\
\hline WOM & $<---$ & KPT & .221 & WOM1 & $<---$ & WOM & .878 & WOM1 \\
\hline SEL & $<---$ & KPT & .760 & SEL3 & $<---$ & SEL & .699 & SEL3 \\
\hline IKT & $<---$ & KPSPK & .653 & SEL2 & $<---$ & SEL & .739 & SEL2 \\
\hline DSR & $<---$ & KPSPK & .462 & SEL1 & $<---$ & SEL & .758 & SEL1 \\
\hline ALH & $<---$ & KPSPK & 1.035 & BELI1 & $<---$ & KPP & .711 & BELI1 \\
\hline IKL3 & $<---$ & IKL & .699 & BELI2 & $<---$ & KPP & .755 & BELI2 \\
\hline IKL2 & $<---$ & IKL & .624 & BELI3 & $<---$ & KPP & .753 & BELI3 \\
\hline IKL1 & $<---$ & IKL & .806 & DSR1 & $<---$ & DSR & .787 & DSR1 \\
\hline PRO3 & $<---$ & PRO & .648 & DSR2 & $<---$ & DSR & .763 & DSR2 \\
\hline PRO2 & $<---$ & PRO & .899 & DSR3 & <--- & DSR & .693 & DSR3 \\
\hline PRO1 & $<---$ & PRO & .594 & IKT1 & <--- & IKT & .726 & IKT1 \\
\hline HUM3 & $<---$ & HUM & .737 & IKT2 & <--- & IKT & .713 & IKT2 \\
\hline HUM2 & $<---$ & HUM & .735 & IKT3 & $<---$ & IKT & .802 & IKT3 \\
\hline HUM1 & $<---$ & HUM & .731 & ALH1 & $<---$ & ALH & .738 & ALH1 \\
\hline ACR3 & $<---$ & ACR & .731 & ALH2 & $<---$ & ALH & .724 & ALH2 \\
\hline
\end{tabular}

Menurut Santoso (2015:138) apabila semua faktor loading (kolom estimate) menunjukkan angka diatas 0,5 maka hal ini menunjukkan semua indikator dapat menjelaskan konstruk yang ada. Berdasarkan Tabel 2, diketahui bahwa seluruh variabel teramati memiliki nilai loading factor lebih dari 0,5 atau $\lambda>0,5$ sehingga variabel-variabel tersebut dinyatakan valid atau layak digunakan dalam model struktural pada penelitian ini.

\section{Uji Reliabilitas Konstruk}

Tabel 3. Hasil Uji Reabilitas Konstruk

\begin{tabular}{cccc}
\hline Dimensi & CR & AVE & Hasil \\
\hline Iklan & 0.775 & 0.509 & Reliable \\
Promosi & 0.764 & 0.527 & Reliable \\
Humas & 0.778 & 0.539 & Reliable \\
Acara & 0.776 & 0.536 & Reliable \\
Pemasaran Langsung & 0.774 & 0.535 & Reliable \\
Pemasaran Interaktif & 0.795 & 0.565 & Reliable \\
WOM & 0.848 & 0.652 & Reliable \\
Personal Selling & 0.776 & 0.536 & Reliable \\
Beli & 0.784 & 0.548 & Reliable \\
Dasar Loyalitas & 0.792 & 0.561 & Reliable \\
Ikatan Loyalitas & 0.792 & 0.560 & Reliable \\
Peralihan Jasa & 0.776 & 0.536 & Reliable \\
\hline
\end{tabular}

Nilai CR yang dihasilkan semua dimensi lebih besar dari batas minimal CR yang disarankan, yaitu 0,70 dan nilai AVE yang dihasilkan semua dimensi juga lebih besar dari batas minimal yang disarankan yaitu 0,50, hal ini menunjukkan bahwa reliabilitas konstruk sudah baik. 
Uji Fit Model. Uji fit model dilakukan dengan melihat nilai Chi-kuadrat, GFI, AGFI, TLI, CFI, CMIN/DF dan RMSEA dapat dilihat pada tabel 4 berikut ini : model dikatakan fit. Menurut Haryono \& Wardoyo (2012:116), jika dari beberapa uji kelayakan model, model dikatakan layak apabila paling tidak salah satu metode uji kelayakan model terpenuhi.

Tabel 4. Goodness-of-Fit Index

\begin{tabular}{l|l|c|c}
$\begin{array}{c}\text { Goodness-of-Fit } \\
\text { Index }\end{array}$ & Cut-off Value & Hasil GOF & Keterangan \\
X ${ }^{2}$ Chi Square & Diharapkan kecil & 806.311 & Tidak fit \\
Significace & $\geq 0,05$ & 0.000 & Tidak fit \\
Probability & $\leq 0,08$ & 0,062 & fit \\
RMSEA & $\geq 0,90$ & 0,707 & Tidak fit \\
GFI & $\geq 0,90$ & 0,664 & Tidak fit \\
AGFI & $\leq 2,00$ & 1,390 & fit \\
CMIN/DF & $\geq 0,95$ & 0,831 & Tidak fit \\
TLI & $\geq 0,95$ & 0,845 & Tidak fit \\
CFI & & &
\end{tabular}

\section{Uji Hipotesis}

(H1): Komunikasi Pemasaran Terpadu (KPT) berpengaruh positif terhadap Keputusan Pembelian Pengunjung (KPP). Hipotesis pertama yang akan diuji adalah pengaruh Komunikasi Pemasaran Terpadu (KPT) terhadap Keputusan Pembelian Pengunjung (KPP). Hubungan kausalitas (pengaruh) KPT terhadap KPP ditunjukkan pada Gambar 2 dimana diperoleh nilai koefisien jalur sebesar 0,679 dengan $\mathrm{R}^{2}=0,461$.

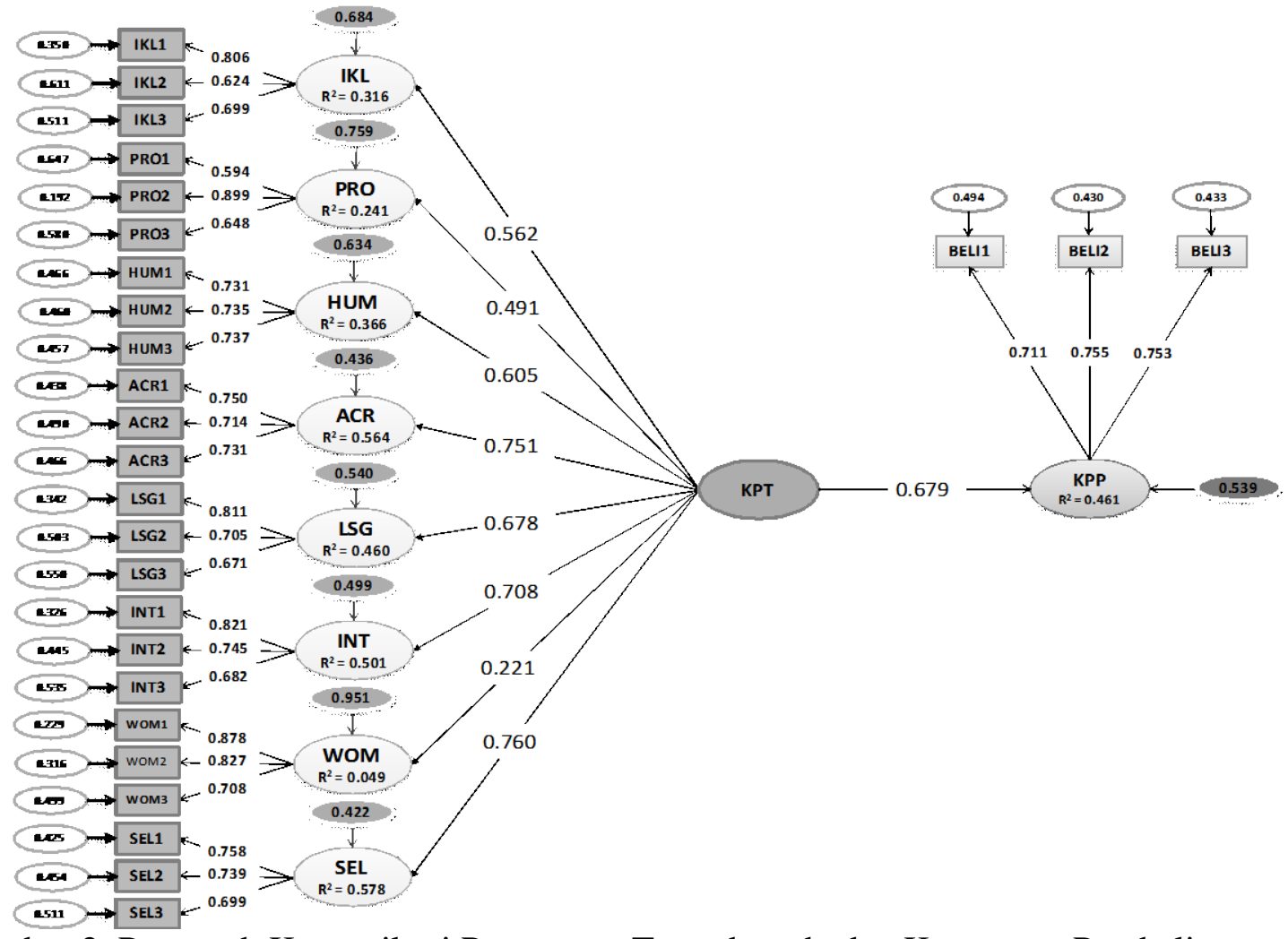

Gambar 2. Pengaruh Komunikasi Pemasaran Terpadu terhadap Keputusan Pembelian Pengunjung (Sumber: Output AMOS diolah) 
Berdasarkan nilai $\mathrm{R}^{2}=0,461$ dapat diketahui Komunikasi Pemasaran Terpadu (KPT) memberikan pengaruh secara langsung terhadap Keputusan Pembelian Pengunjung (KPP) sebesar 46,1\%. Ini berarti bahwa KPT memberikan pengaruh 46,1\% terhadap KPP jika tidak ada variabel lainnya yang diperhatikan. Berikut ini disajikan hasil uji signifikansi dari hipotesis tersebut melalui hipotesis statistik sebagai berikut: hasil uji hipotesis pertama menunjukkan bahwa nilai koefisien jalur sebesar 0,679 dengan nilai thitung sebesar 3,412. Nilai t-statistik yang diperoleh 3,412 lebih besar dari tabel 1,984. Dengan demikian berdasarkan hasil pengujian dapat dikatakan bahwa KPT berpengaruh signifikan terhadap KPP.

Berdasarkan hasil analisis, nilai loading factor tiap-tiap dimensi dari variabel Komunikasi Pemasaran Terpadu (KPT) apabila diurutkan dari yang paling besar adalah personal selling $(0,760)$, acara khusus dan pengalaman $(0,751)$, pemasaran interaktif $(0,708)$, pemasaran langsung $(0,678)$, hubungan masyarakat dan publisitas $(0,605)$, iklan $(0,562)$, promosi penjualan $(0,491)$ dan yang paling terendah adalah dimensi word of mouth $(0,221$

(H2): Keputusan Pembelian Pengunjung (KPP) berpengaruh positif terhadap Keputusan Perpanjangan Sewa Penyewa Kios (KPSPK).Hipotesis kedua yang akan diuji adalah pengaruh Keputusan Pembelian Pengunjung (KPP) terhadap Keputusan Perpanjangan Sewa Penyewa Kios (KPSPK). Hubungan kausalitas (pengaruh) KPP terhadap KPSPK ditunjukkan pada Gambar 3 dimana diperoleh nilai koefisien jalur sebesar 0,239 dengan $\mathrm{R}^{2}=0,057$.

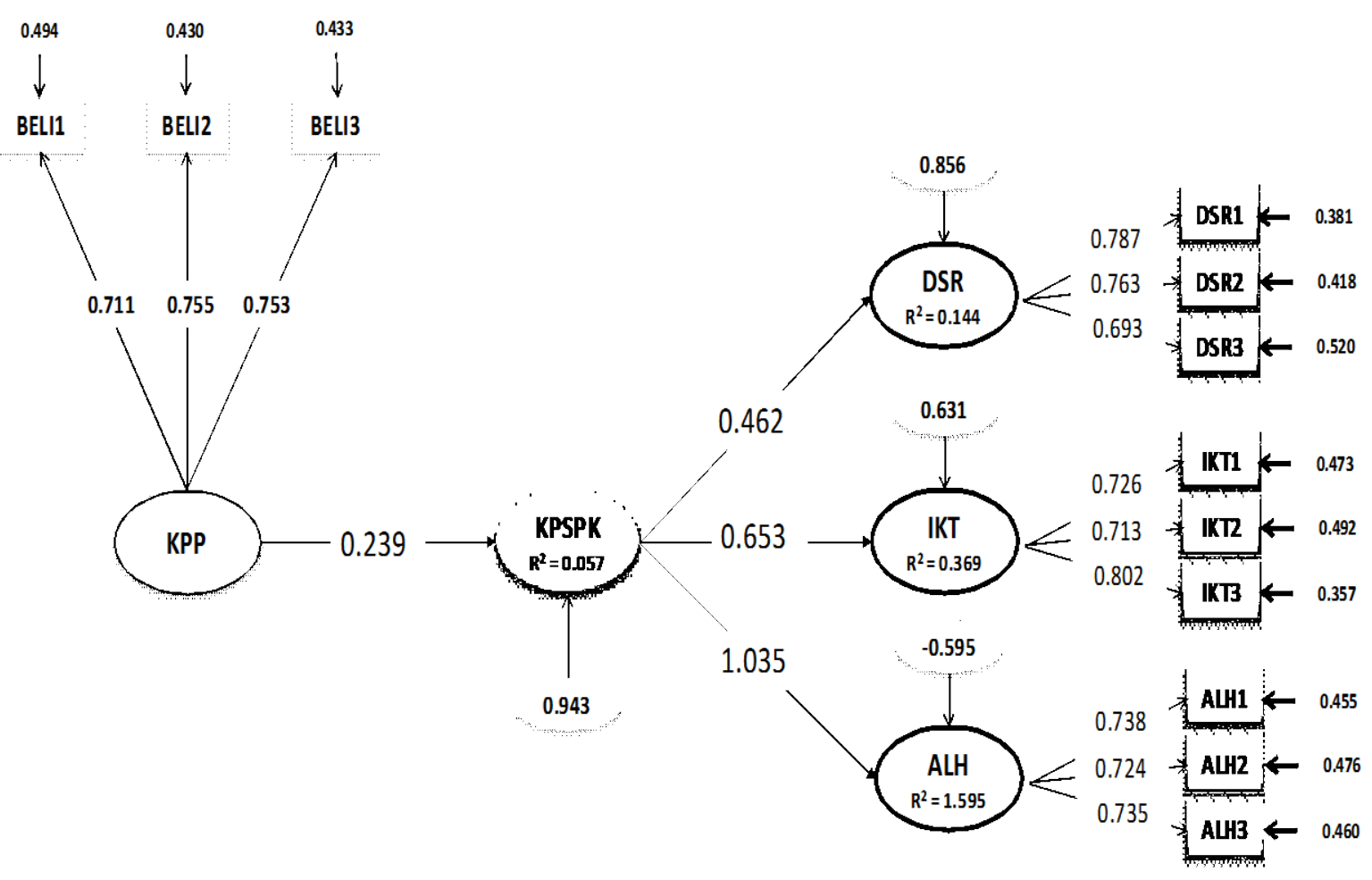

Gambar 3. Pengaruh Keputusan Pembelian Pengunjung terhadap Keputusan

Perpanjangan Sewa Penyewa Kios

Sumber: Output AMOS diolah) 
Berdasarkan nilai $\mathrm{R}^{2}=0,057$ dapat diketahui Keputusan Pembelian Pengunjung (KPP) memberikan pengaruh secara langsung terhadap Keputusan Perpanjangan Sewa Penyewa Kios (KPSPK) sebesar 5,7\%. Ini berarti bahwa KPP memberikan pengaruh 5,7\% terhadap KPSPK jika tidak ada variabel lainnya yang diperhatikan. Selanjutnya dilakukan uji signifikansi pengaruh parsial KPP terhadap KPSPK. Berikut ini disajikan hasil uji signifikansi dari hipotesis tersebut melalui hipotesis statistik sebagai berikut:

$\mathrm{H}_{0} \cdot \gamma_{11}=0$ : KPP tidak berpengaruh signifikan terhadap KPSPK

$\mathrm{H}_{1} \cdot \gamma_{11} \neq 0$ : KPP berpengaruh signifikan terhadap KPSPK

Berdasarkan hasil uji hipotesis kedua menunjukkan bahwa nilai koefisien jalur sebesar 0,239 dengan nilai thitung sebesar 1,228. Nilai nilai t-statistik yang diperoleh $(1,228)$ lebih kecil dari tabel $(1,984)$. Dengan demikian berdasarkan hasil pengujian dapat dikatakan bahwa KPP tidak berpengaruh signifikan terhadap KPSPK.

Diantara seluruh dimensi pada variabel Keputusan Perpanjangan Sewa Penyewa Kios (KPSPK), dimensi (peralihan jasa/service switching) mempunyai nilai loading factor yang paling tinggi yaitu sebesar 1,035 kemudian disusul oleh dimensi ikatan loyalitas dengan loading factor sebesar 0.653. Sedangkan untuk dimensi yang nilai loading factor yang paling rendah adalah dimensi dasar loyalitas dengan nilai 0,462.

(H3) : Komunikasi Pemasaran Terpadu (KPT) berpengaruh positif terhadap Keputusan Perpanjangan Sewa Penyewa Kios (KPSPK)

Hipotesis ketiga yang akan diuji adalah pengaruh Komunikasi Pemasaran Terpadu (KPT) terhadap Keputusan Perpanjangan Sewa Penyewa Kios (KPSPK). Hubungan kausalitas (pengaruh) KPT terhadap KPSPK ditunjukkan pada Gambar 4 dimana diperoleh nilai koefisien jalur sebesar 0,263 dengan $\mathrm{R}^{2}=0,069$.

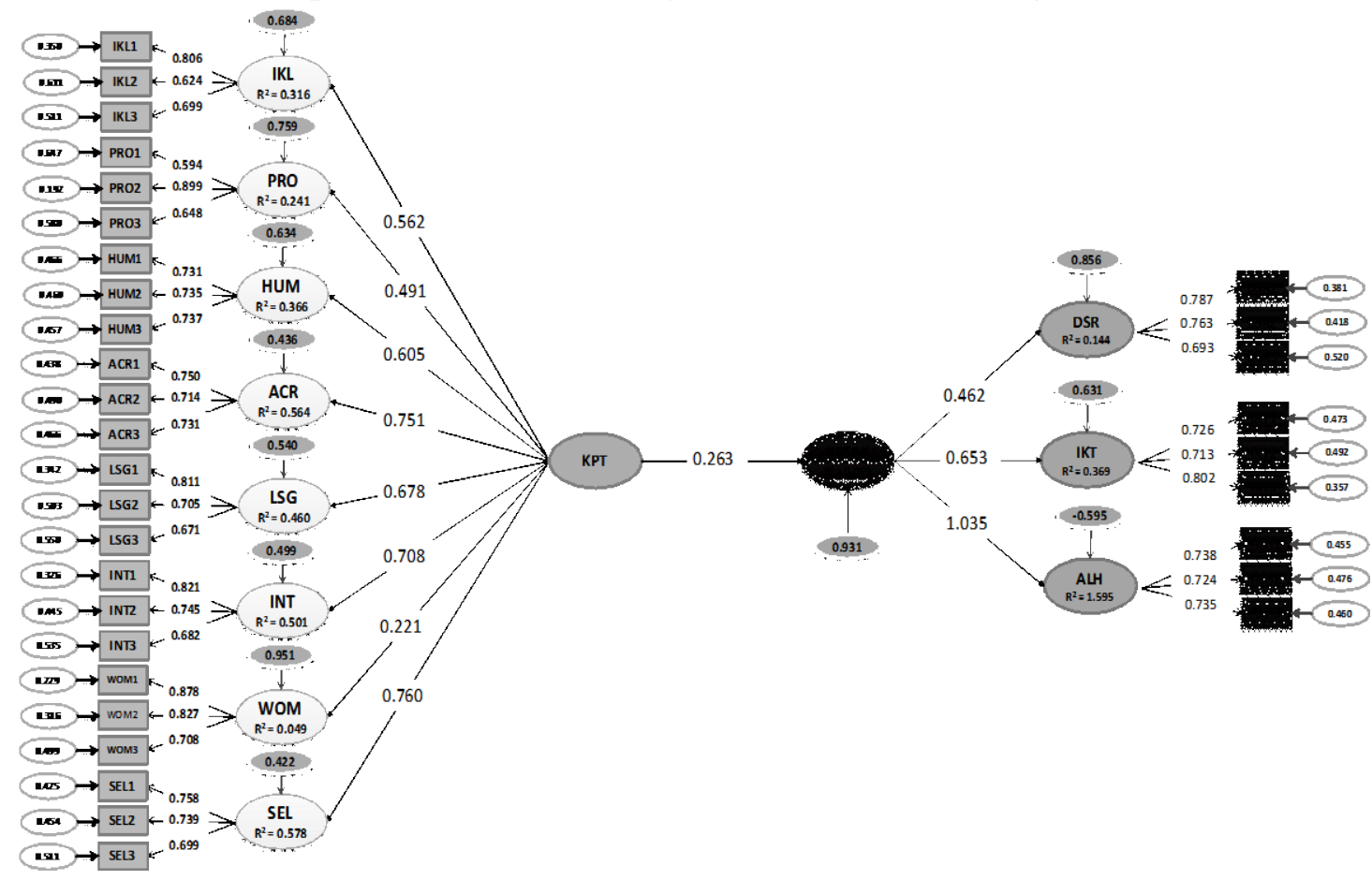

Gambar 4. Pengaruh Komunikasi Pemasaran Terpadu terhadap Keputusan Perpanjangan Sewa Penyewa Kios (Sumber: Output AMOS diolah) 
Berdasarkan nilai $\mathrm{R}^{2}=0,069$ dapat diketahui Komunikasi Pemasaran Terpadu (KPT) memberikan pengaruh secara langsung terhadap Keputusan Perpanjangan Sewa Penyewa Kios (KPSPK) sebesar 6,9\%. Ini berarti bahwa KPT memberikan pengaruh 6,9\% terhadap KPSPK jika tidak ada variabel lainnya yang diperhatikan. Selanjutnya dilakukan uji signifikansi pengaruh parsial KPT terhadap KPSPK. Berikut ini disajikan hasil uji signifikansi dari hipotesis tersebut melalui hipotesis statistik sebagai berikut:

$\mathrm{H}_{0} \cdot \gamma_{11}=0 \quad$ KPT tidak berpengaruh signifikan terhadapKPSPK

\section{$\mathrm{H}_{1} \cdot \gamma_{11} \neq 0 \quad$ KPT berpengaruh signifikan terhadap KPSPK}

Berdasarkan hasil uji hipotesis ketiga menunjukkan bahwa nilai koefisien jalur sebesar 0,263 dengan nilai thitung sebesar 1,293. Nilai t-statistik yang diperoleh $(1,293)$ lebih kecil dari $t_{\text {kritis }}$ (1,984). Dengan demikian berdasarkan hasil pengujian dapat dikatakan bahwa Komunikasi Pemasaran Terpadu tidak berpengaruh signifikan terhadap Keputusan Perpanjangan Sewa Penyewa Kios.

Structure Equation Modelling (SEM) dengan Responden Pengunjung. Uji Normalitas Santoso (2015:82) mengatakan pengujian normalitas seharusnya tidak perlu dilakukan, karena secara nature, data ordinal bukan data kuantitatif yang mesti memenuhi asumsi normalitas. Santoso (2015:82) juga mengatakan bahwa dalam banyak riset, walaupun terdapat data yang dikategorikan outlier data tersebut tetap disertakan pada proses pengolahan data. Data pendapat responden betapa pun biasnya, tetap sebuah fakta yang harus diperhitungkan sebagai temuan.

Uji Validitas Konstruk. Menurut Santoso (2015:138) apabila semua faktor loading (kolom estimate) menunjukkan angka diatas 0,5 maka hal ini menunjukkan semua indikator dapat menjelaskan konstruk yang ada. Berdasarkan output AMOS diperoleh bahwa seluruh variabel teramati memiliki nilai loading factor lebih dari 0,5 atau $\lambda>0,5$ sehingga variabel-variabel tersebut dinyatakan valid atau layak digunakan dalam model struktural pada penelitian ini.

Uji Reliabilitas Konstruk. Nilai CR yang dihasilkan semua dimensi ( iklan, promosi, humas, acara, pemasaran langsung, pemasaran interaktif, WOM,personal selling dan beli) lebih besar dari batas minimal CR yang disarankan, yaitu 0,70 dan nilai AVE yang dihasilkan semua dimensi juga lebih besar dari batas minimal yang disarankan yaitu 0,50, hal ini menunjukkan bahwa reliabilitas konstruk sudah baik.

Modifikasi Model Responden Pengunjung. Menurut Supriyadi (2014:247) untuk melakukan modifikasi model secara overall dapat dilakukan dengan membuat covariance antara variabel error. Caranya dengan membuka diagram awal dan lalu ditambahkan covariance atau panah dua arah antara dua error dengan dasar melihat nilai M.I (Modification Indices) yang terbesar.

Dengan melihat nilai MI (Modification Indices), maka modifikasi dilakukan dengan menghubungkan error antar indikator variabel yang sama. Penulis juga menghubungkan error dari variabel yang berbeda yaitu e45 dengan e37 dimana e45 merupakan error untuk penilaian dimensi personal selling terhadap error variabel keputusan pembelian pengunjung. Hal ini dilakukan karena secara parsial dimensi personal selling juga dapat langsung mempengaruhi keputusan pembelian pengunjung. Menurut Kotler dan Keller (2012:562), prinsip-prinsip personal selling dan negosiasi sebagian besar berorientasi 
transaksi karena tujuan mereka adalah untuk menutup penjualan tertentu. Penelitian dampak langsung personal selling terhadap penjualan atau keputusan pembelian juga pernah dilakukan oleh Murithi (2015), Kardena (2014) dan Aryanto (2008).

Uji Validitas Konstruk. Berikut ini merupakan hasil validitas konstruk pada model yang telah dimodifikasi. Dihasilkan bahwa seluruh variabel teramati memiliki nilai loading factor lebih dari 0,5 atau $\lambda>0,5$ sehingga variabel-variabel tersebut dinyatakan valid atau layak digunakan dalam model struktural pada penelitian ini.

Uji Reliabilitas Konstruk. Nilai CR yang dihasilkan semua dimensi lebih besar dari batas minimal CR yang disarankan yaitu 0,70 dan nilai AVE yang dihasilkan semua dimensi juga lebih besar dari batas minimal yang disarankan yaitu 0,50 , hal ini menunjukkan bahwa reliabilitas konstruk sudah baik.

Uji Fit Mode. Uji fit model dilakukan dengan melihat nilai Chi-kuadrat, GFI, AGFI, TLI, CFI, CMIN/DF dan RMSEA dapat dijelaskan sebagai berikut: diperoleh nilai Chi-kuadrat sebesar 560.969 dengan $p$-value 0.000. Dikarenakan p-value yang dihasilkan sangat kecil (lebih kecil dari $\alpha=5 \%$ ), maka model dikatakan tidak fit. Indeks fit GFI, AGFI, TLI dan CFI yang dihasilkan nilainya masing-masing hanya 0,$772 ; 0,633 ; 0,849$ san 0,867 . Dikarenakan GFI, AGFI, TLI dan CFI lebih kecil dari 0,90, maka mengindikasikan bahwa model tidak fit. Nilai CMIN/DF yang diperoleh sebesar 1,810, nilai tersebut $<2,00$ dan mengindikasikan bahwa model fit dan nilai RMSEA yang dihasilkan sebesar yaitu 0,078, dikarenakan nilai ini lebih besar dari 0,08 maka model dikatakan fit.

Menurut Haryono \& Wardoyo (2012:116) dari beberapa uji kelayakan model, model dikatakan layak jika paling tidak salah satu metode uji kelayakan model terpenuhi. Dari Tabel 16, terlihat ada 2 metode uji kelayakan model yang fit, ini berarti model ini layak untuk dilanjutkan.

Uji Hipotesis. Setelah dilakukan uji fit model selanjutnya dilakukan uji hipotesis dengan tujuan untuk mengetahui apakah hipotesis peneliti diterima atau ditolak. Berikut ini merupakan diagram hasil perhitungan dengan menggunakan program AMOS 16.

Hipotesis :Komunikasi Pemasaran Terpadu (KPT) berpengaruh positif terhadap Keputusan Pembelian Pengunjung (KPP)

Hipotesis yang akan diuji adalah pengaruh KPT terhadap KPP. Hubungan kausalitas (pengaruh) KPT terhadap KPP ditunjukkan pada gambar 4.8 dimana diperoleh nilai koefisien jalur sebesar 0,594 dengan $\mathrm{R}^{2}=0$,

Berdasarkan Gambar 4 nilai $\mathrm{R}^{2}=0,352$ dapat diketahui Komunikasi Pemasaran Terpadu (KPT) memberikan pengaruh secara langsung terhadap Keputusan Pembelian Pengunjung (KPP) sebesar 35,2\%. Ini berarti bahwa KPT memberikan pengaruh 35,2\% terhadap KPP jika tidak ada variabel lainnya yang diperhatikan. Selanjutnya dilakukan uji signifikansi pengaruh parsial KPT terhadap KPP. Berikut ini disajikan hasil uji signifikansi dari hipotesis tersebut melalui hipotesis statistik sebagai berikut:

$\mathrm{H}_{0 .} \gamma_{11}=0 \quad$ KPT tidak berpengaruh signifikan terhadap KPP

$\mathrm{H}_{1} . \gamma_{11} \neq 0 \quad$ KPT berpengaruh signifikan terhadap KPP 


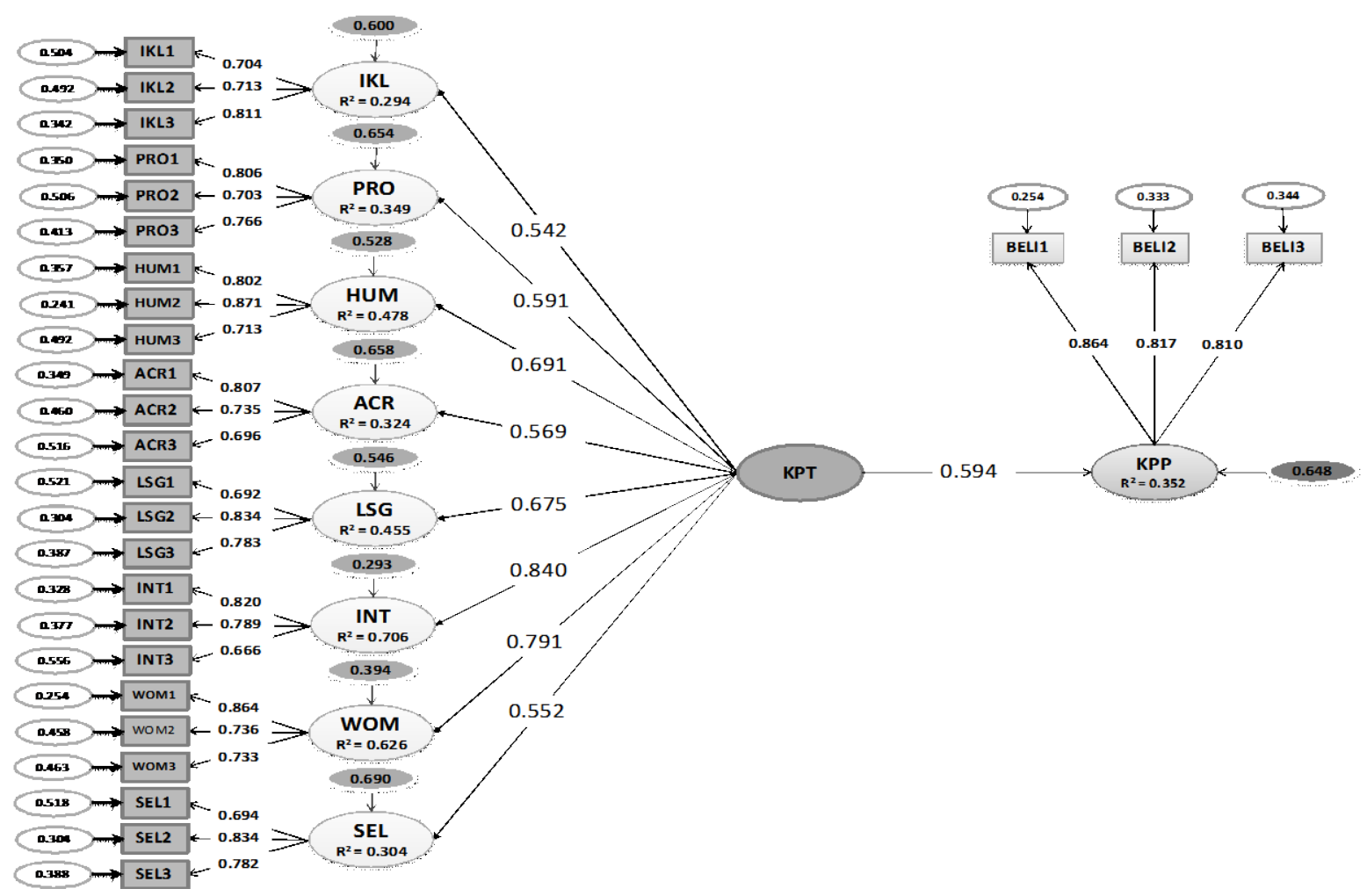

Gambar 4. Pengaruh Komunikasi Pemasaran Terpadu terhadap Keputusan Perpanjangan Sewa Penyewa Kios (Sumbe : Output AMOS diolah)

Uji Signifikansi Pengaruh KPT terhadap KPP. Berdasarkan hasil uji hipotesis menunjukkan bahwa nilai koefisien jalur sebesar 0,594 dengan nilai thitung sebesar 4,254. Nilai nilai t-statistik yang diperoleh $(4,254)$ lebih besar dari thitung $(1,978)$. Dengan demikian berdasarkan hasil pengujian dapat dikatakan bahwa komunikasi pemasaran terpadu (KPT) berpengaruh signifikan terhadap keputusan pembelian pengunjung (KPP).

Dari Gambar 4, kita dapat melihat nilai loading factor tiap-tiap dimensi dari variabel Komunikasi Pemasaran Terpadu (KPT) apabila diurutkan dari yang paling besar adalah pemasaran interaktif $(0,840)$, word of mouth $(0,791)$, hubungan masyarakat dan publisitas $(0,691)$, pemasaran langsung $(0,675)$, promosi penjualan $(0,591)$ personal selling $(0,552)$ dan yang paling terendah adalah dimensi iklan $(0,542)$.

Pembahasan. Hasil uji hipotesis $1\left(\mathrm{H}_{1}\right)$ baik dari sudut pandang pengunjung maupun penyewa kios menunjukkan adanya pengaruh yang signifikan dari komunikasi pemasaran terpadu terhadap keputusan pembelian pengunjung. Hal ini sesuai dengan framework dari komunikasi pemasaran terpadu Shimp (2010:20), dimana komunikasi pemasaran terpadu digunakan untuk mempengaruhi perilaku dalam hal ini perilaku konsumen. Outcome dari komunikasi terpadu ini berupa keputusan pembelian konsumen. Jadi dapat disimpulkan bahwa strategi komunikasi pemasaran terpadu yang kuat kepada pengunjung mall akan berdampak terhadap meningkatnya penjualan tenant. Hasil penelitian ini mendukung penelitian dari Larasati (2015), Devi \& Giantari (2014) dan Radinka (2012), dimana komunikasi pemasaran terpadu berpengaruh signifikan terhadap keputusan pembelian. Berdasarkan hasil penelitian, dimensi dari komunikasi pemasaran terpadu yang dominan mempengaruhi pembelian pengunjung mall menurut penyewa kios adalah dimensi 
personal selling. Hasil penelitian ini juga mendukung penelitian dari Larasati (2015) dimana personal selling adalah bauran yang paling mempengaruhi keputusan pembelian jasa travel diantara media komunikasi pemasaran lainnya. Bentuk personal selling yang dilakukan oleh mall adalah bentuk personal selling yang dilakukan oleh petugas customer service, resepsionis dan petugas mall lainnya. Menurut Sunyoto (2015:25) dalam bisnis retail, customer service adalah salah satu poin penting yang harus diperhatikan, agar pelanggan bisa datang kembali. Sunyoto (2015:25) juga menyatakan bahwa perlu dilakukan pelatihan SDM (Sumber Daya Manusia) agar bisa memberikan pelayanan terbaik kepada pelanggan. Ini berarti pengelola harus memberikan bekal pengetahuan produk (product knowledge) yang cukup agar dapat menangani keluhan pengunjung dan memberikan informasi yang tepat atas kebutuhan pengunjung melalui pelatihan-pelatihan. Petugas customer service, resepsionis dan petugas mall juga harus dilatih agar memiliki kemampuan komunikasi yang efektif (effective communication skill).

Menurut penyewa kios, dimensi dari komunikasi pemasaran terpadu yang paling rendah adalah word of mouth. Saat ini, PS Mall hanya mengandalkan kata positif dari mulut ke mulut secara oral. Dengan perkembangan teknologi, ternyata word of mouth kini juga dapat dikelola dan difasilitasi melalui berbagai bentuk media sosial. Hal ini sangat efektif untuk usaha kecil, dengan siapa pelanggan mungkin merasa hubungan yang lebih pribadi. Banyak usaha kecil yang berinvestasi dalam berbagai bentuk media sosial dengan mengorbankan surat kabar, radio, dan Yellow Pages untuk mendapatkan word out. Perusahaan dapat memanfaatkan cerita berita, blog, percakapan jaringan sosial yang berhubungan dengan produk mereka. Menurut Kotler \& Keller (2012:546), sosial media memungkinkan pemasar untuk membangun opini publik dan kehadiran mereka di web. Selain itu juga dapat memperkuat kegiatan komunikasi lainnya. Dan kini, media sosial juga dapat mendorong perusahaan untuk tetap inovatif dan relevan.

Menurut pengunjung, dimensi komunikasi pemasaran terpadu yang paling dominan mempengaruhi adalah pemasaran interaktif. Indikator yang paling lemah diantara seluruh indikator dari dimensi ini adalah kepercayaan pengunjung terhadap informasi yang mereka terima melalui interaksi secara online. Kotler \& Keller (2012:542) menyatakan perusahaan harus peka terhadap keamanan dan privasi perlindungan masalah online. Perusahaan dapat melakukan tracking dimana konsumen online melalui tampilan halaman, lama kunjungan. Perusahaan juga harus peka terhadap keamanan dan privasi perlindungan masalah online.

Untuk dimensi dengan nilai loading factor paling rendah diantara dimensi komunikasi pemasaran terpadu menurut pengunjung adalah iklan. Indikator yang paling lemah adalah menarik atau tidaknya perpaduan warna dan tema gambar dari iklan yang dicetak Menurut Hermawan (2012:76), perpaduan warna yang menarik adalah salah satu prinsip dari efektifitas iklan, demikian pula dengan tema gambar. Iklan haruslah kreatif, mempunyai cita rasa, menonjol dan mudah diingat.

Pada uji hipotesa $2\left(\mathrm{H}_{2}\right)$, hasil temuan menunjukkan bahwa keputusan pembelian pengunjung ternyata tidak mempengaruhi keputusan perpanjangan kontrak sewa penyewa kios di PS Mall secara signifikan. Ini berarti keuntungan yang diperoleh tenant dari hasil penjualan mereka di PS Mall, bukanlah faktor utama dalam menentukan keputusan perpanjangan sewa oleh penyewa kios di PS Mall. Menurut informasi yang didapatkan dari pengelola PS Mall rata-rata tenant di PS Mall menyewa langsung selama 5-10 tahun dengan sistem kontrak dan invoice ditagihkan per tahunnya. Selain itu 56,4\% atau lebih dari setengah penyewa kios adalah tenant nasional/internasional, dimana tenant 
nasional/internasional biasanya mempunyai pendanaan yang kuat. Menurut Sunyoto (2015:22), perusahaan begitu sedikit mencetak laba pada awalnya maka perusahaan harus mencari uang dari beberapa sumber lain selama fase awal operasi bisnis mereka. Sunyoto (2015:22) juga mengatakan dalam mengelola bisnis retail biasanya membutuhkan waktu 15-20 tahun untuk mencapai kesuksesan. Jadi apabila pengusaha bisnis retail tidak mempunyai dana yang cukup kuat maka mereka tidak akan mampu bertahan.

Keputusan perpanjangan kontrak sewa penyewa kios di PS Mall dipengaruhi oleh keputusan pembelian pengunjung sebesar 5,7\% dan sisanya 94,3\% dipengaruhi oleh faktor lain yang tidak diteliti. Faktor lain tersebut dapat merujuk dari penelitian Sinchaloenman \& Ngamyan (2013), dimana diketahui faktor kunci yang dapat mempengaruhi keputusan perpanjangan kontrak sewa tenant, terutama tenant kecil adalah Trust (kepercayaan) hal ini dapat terbentuk melalui 2 faktor yaitu: Responsive Behavior dan Empowerment. Perilaku responsif tersebut terbentuk dari reaksi pengelola mall dalam membantu dan menangani masalah yang dihadapi tenant. Sedangkan pada faktor empowerment, tenant kecil ini sangat memperhatikan masalah perbedaan harga sewa yang ditetapkan oleh pengelola.

Pada hipotesis $3\left(\mathrm{H}_{3}\right)$ juga menunjukkan pengaruh langsung yang tidak signifikan antara komunikasi pemasaran terpadu terhadap keputusan perpanjangan sewa penyewa kios. Ini berarti komunikasi pemasaran terpadu yang dilakukan oleh pengelola PS Mall tidak menciptakan ikatan loyalitas yang kuat antara tenant dengan pengelola. Hal ini dapat terjadi karena hampir semua tenant baik lokal maupun nasional/internasional tidak terlalu tergantung dengan media komunikasi pemasaran terpadu yang dikelola oleh PS Mall. Hampir dari semua tenant mempunyai media komunikasi pemasaran sendiri yang digunakan untuk mempromosikan produk mereka terutama tenant nasional/internasional.

Berdasarkan hasil uji hipotesis tersebut, pengelola PS Mall harus mulai memperhatikan faktor-faktor lain yang dapat membangun loyalitas penyewa kios dan bukan hanya memperhatikan strategi komunikasi pemasaran saja. Menurut Lovelock \& Wirtz (2011:345), kepuasan dan kualitas layanan yang baik merupakan syarat awal terbentuknya loyalitas. Oleh sebab itu pengelola terlebih dahulu harus memberikan kepuasan dan kualitas layanan yang baik kepada penyewa kios di PS Mall agar terbentuk dasar loyalitas yang kuat.

Setelah dasar loyalitas terbangun, pengelola dapat menciptakan ikatan yang lebih dekat dengan penyewa kios. Menurut Lovelock \& Wirtz (2011:353) menciptakan ikatan loyalitas dapat dilakukan dengan cara yaitu mempererat hubungan (deeping the relationship), mendorong keloyalitasan dengan memberikan penghargaan finansial maupun non-finansial. Penghargaan finansial misalnya dengan pemberian harga spesial bila mereka melakukan perpanjangan sewa. Sedangkan penghargaan non-finansial adalah pemberian manfaat atau keuntungan yang biasanya berkaitan dengan inti jasa perusahaan. Pengelola dapat memberikan perhatian-perhatian khusus sehingga mereka merasa dihargai dan membuat mereka merasa ada ikatan khusus dengan pengelola PS Mall, misalnya dengan pemberian reward kepada tenant yang turut berpartisipasi terhadap kemajuan mall. Disamping itu pengelola juga harus berusaha mengurangi terjadinya kehilangan pelanggan mereka yaitu penyewa kios. Lovelock \& Wirtz (2011:358) mengatakan untuk menghilangkan atau mengurangi faktor pendorong terjadinya kehilangan pelanggan dapat dilakukan dengan menganalisa kehilangan pelanggan dan memonitor angka penurunan dengan cara pengelola dapat melakukan wawancara atau meminta penyewa kios untuk mengisi formulir secara tertulis, alasan mereka tidak memperpanjang sewa kios. 


\section{PENUTUP}

Simpulan. Berdasarkan hasil perhitungan dan analisis yang telah dilakukan pada bab sebelumnya, maka diperoleh beberapa kesimpulan sebagai berikut: Pertama. Pada model dimana penyewa kios/tenant sebagai responden dapat diketahui bahwa: (1) Komunikasi Pemasaran Terpadu yang dilakukan oleh PS Mall berpengaruh signifikan terhadap Keputusan Pembelian Pengunjung dengan persentase pengaruh sebesar 46,1\% dan sisanya sebesar 53,9\% merupakan pengaruh dari faktor lain yang tidak diteliti; (2) Diketahui juga bahwa keputusan pembelian pengunjung ternyata tidak berpengaruh signifikan terhadap keputusan perpanjangan sewa penyewa kios; (3) Komunikasi pemasaran terpadu ternyata secara langsung juga tidak berpengaruh signifikan terhadap keputusan perpanjangan sewa penyewa kios; (4) Komunikasi pemasaran terpadu yang dilakukan oleh PS Mall berpengaruh signifikan terhadap keputusan pembelian pengunjung dengan persentase pengaruh sebesar $35,2 \%$ dan sisanya sebesar $64,8 \%$ merupakan pengaruh dari faktor lain yang tidak diteliti.

Saran. Saran bagi Pengelola Palembang Square Mall. Berikut ini adalah saran yang dapat dikemukakan kepada pengelola PS Mall:

1. PS Mall dalam memutuskan media iklan haruslah memperhatikan faktor kunci seperti jangkauan iklan, intensitas atau berapa kali iklan harus dicetak/diterbitkan agar dapat mendorong konsumen ke arah iklan, dampak iklan dan waktu penayangan. Menarik atau tidaknya perpaduan warna dan tema gambar dari iklan yang dicetak juga harus diperhatikan.

2. Saat ini, metode word of mouth yang digunakan oleh pengelola PS Mall masih bersifat oral dari orang ke orang (people to people). Dengan canggihnya teknologi komunikasi saat ini, peneliti sangat menganjurkan kepada pengelola untuk mencoba meningkatkan efektifitas dari word of mouth melalui media sosial atau internet. Word out atau opini dari pelanggan melalui blog, media sosial, forum atau komunitas online yang trend saat ini pun dapat mulai dimanfaatkan oleh pengelola PS Mall.

3. Pengelola PS Mall harus mulai memperhatikan faktor-faktor lain yang lebih berpengaruh terhadap keputusan perpanjangan sewa penyewa kios. Untuk membangun dasar loyalitas penyewa kios, pengelola terlebih dahulu harus memberikan kepuasan dan kualitas layanan yang baik kepada penyewa kios di PS Mall. Faktor lain yang dapat diperhatikan oleh pengelola untuk mempengaruhi keputusan perpanjangan kontrak penyewa kios adalah Trust (Kepercayaan). Trust ini dapat dibentuk dari sikap responsif atau bagaimana cara pengelola menangani dan membantu permasalahan dan kesulitan yang dihadapi penyewa- penyewa kios.

\section{DAFTAR PUSTAKA}

Adriyanto, R. D dan Jony O. Haryanto. (2010) Analisis Pengaruh Internet Marketing terhadap Pembentukan Word of Mouth dan Brand Awareness untuk Memunculkan Intention to Buy. Jurnal Manajemen Teknologi. Volume 9 No.1

Alam, Ardian. (2015) Pengaruh Bauran Promosi terhadap Keputusan Pembelian Konsumen pada Bisnis Waralaba (Studi Kasus pada Restoran Mr. Pancake Solo Paragon Mall).

Aryanto, D. (2008) Personal Selling dan Keputusan Membeli Nasabah (Studi Korelasional 
Personal Selling Asuransi Kerugian terhadap Keputusan Membeli Nasabah di PT. Fadent Mahkota Sahid Medan.

Avello, Maria., Diana. Gavilan, Carmen. Abril and Roberto.Manzano, (2011) "Experiential Shopping at The Mall: Influence on Consumer Behavior". China-USA Business Review. 10 (1). ISSN: 1537-1514.

Devi, I.A.C.S.N dan Giantari ,I.G.A.K. (2014) "Pengaruh Bauran Komunikasi Pemasaran terhadap Keputusan Pembelian Konsumen Provider Tri di Kota Denpasar”. EJurnal Manajemen Universitas Udayana, 3 (7)

Devvy, N. (2013) Analisis Strategi Komunikasi Pemasaran Dalam Meningkatkan Jumlah Konsumen Solo Grand Mall.

Dwipuspita, S., Slamet. Mulyana dan Funny. M. Elita. (2012) "Pengaruh Penggunaan Website terhadap Keputusan Pembelian”. eJournal Mahasiswa Universitas Padjajaran. 1 (1).

Ferdinand, A. (2002) Structural Equation Modeling dalam Penelitian Manajemen. Edisi 2. BP UNDIP. Semarang.

Haqie, F. Z. B. (2015) Analisis Strategi Marketing Communication Solo Paragon Lifestyle Mall dalam Meningkatkan Jumlah Pengunjung.

Haryono, S dan P. Wardoyo. (2012) Structural Equation Modelling Untuk Penelitian Manajemen Menggunakan Amos 18. Jawa Barat: PT. Intermedia Personalia Utama.

Hermawan, A. (2012) Komunikasi Pemasaran. Erlangga. Jakarta.

Kardena, D. (2014) Pengaruh Personal Selling terhadap Proses Keputusan Pembelian Sepeda Motor Honda (Studi pada Konsumen PT. Sinar Rejeki Lembang).

Kotler, P. and K. L. Keller. (2012) Marketing Management. 14th edition. Prentice Hall International. New Jersey.

Larasati, Mayang. (2015) Analisis Pengaruh Integrated Marketing Communication terhadap Keputusan Pembelian Jasa pada PT.Ero PrimaWisata.

Lovelock, C. and J.Wirtz. (2011) Services Marketing, 7 th Edition. Pearson. England.

Murithi, M.M. January, (2015) "Effects of Personal Selling on Sales: A Case of Women Groups in Imenti North District, Meru County, Kenya”. International Journal of Academic Research in Business and Social Sciences, 5 (1) ISSN: 2222-6990

Nasir, N. K., N.A. Q. M. Jusoh, A. K. Ramin and N. S. Yee. (2013) Determinants of Tenants'Satisfaction: a Case Study in XXX Parade, Muar 2nd International Conference on technology Management, Business and Enterprenuership. Mahkota Hotel Melaka Malaysia. 5th December 2013. ISSN: 978-967-0468-56-3.

Peter, J. P and J. C. Olson. (2010) Consumer Behaviour \& Marketing Strategy. 9th ed.McGraw-Hill. New York.

Rini, E. S. (2009) ”Menciptakan Pengalaman Konsumen dengan Expriential Marketing”. Jurnal Manajemen Bisnis. 2 (1)

Santoso, S. (2015) AMOS 22 untuk Structural Equation Modelling. Elex Media Komputindo. Jakarta.

Shimp, T. (2010) Advertising, Promotion \& Other Aspects of Integrated Marketing Communication. 8 th Edition. Cengage. Canada.

Sinchaloenman, B and A. Ngamyan. (2013) "Key Factors Affecting Small Tenant Decision on Renewing Shopping Mall Rent Contract”. International Jurnal of Scientific and Research Publication. 3 (12) ISSN : 2250-3153. 